\title{
Terrestrial Magnetism
}

\section{and \\ Atmospheric Electricity}

VOLUME VII

MARCH 1902

NUMBER I

\section{FORTHCOMING ADVANCES IN THE TERRESTRIAL MAGNETISM OF ANTARCTICA.}

By G. W. LITILEhaLES.

Under the imperial flags of Great Britain and Germany, two co-operating expeditions equipped with exceptional completeness, are penetrating into the high southern latitudes for the advance of knowledge concerning the south polar regions.

The main purposes are to determine, as far as possible, the extent and nature of the south polar land, to ascertain the nature of its glaciation and the condition of the ice-cap, to observe the condition of the underlying rocks, and to make a magnetic survey south of $40^{\circ}$ of south latitude. Much importance is also attached to the meteorological observations, and especially in the regions south of $74^{\circ}$ of south latitude. Deep-sea soundings with temperatures are to be taken, and biological observations are likewise to be made. Observations of atmospheric electricity and of polar lights are also provided for in the program.

The German expedition, under the direction of Dr. Erich von Drygalski, Professor in the University of Berlin, will have for its field of investigation the Indo-Atlantic side of the Antarctic region. It has established a base-station at Kerguelen Island, where magnetic and meteorological instruments have been installed for the purpose of keeping a continuous register of meteorological and magnetic phenomena during the time the expedition is engaged in investigations amongst the Antarctic lands. Dr. Karl Luyken, of Dïsseldorf, will have charge of the magnetic and meteorological observations at this station. In addition, a base-station is to be established in the Antarctic regions, where, under the direction of 
[PIATE 1.]

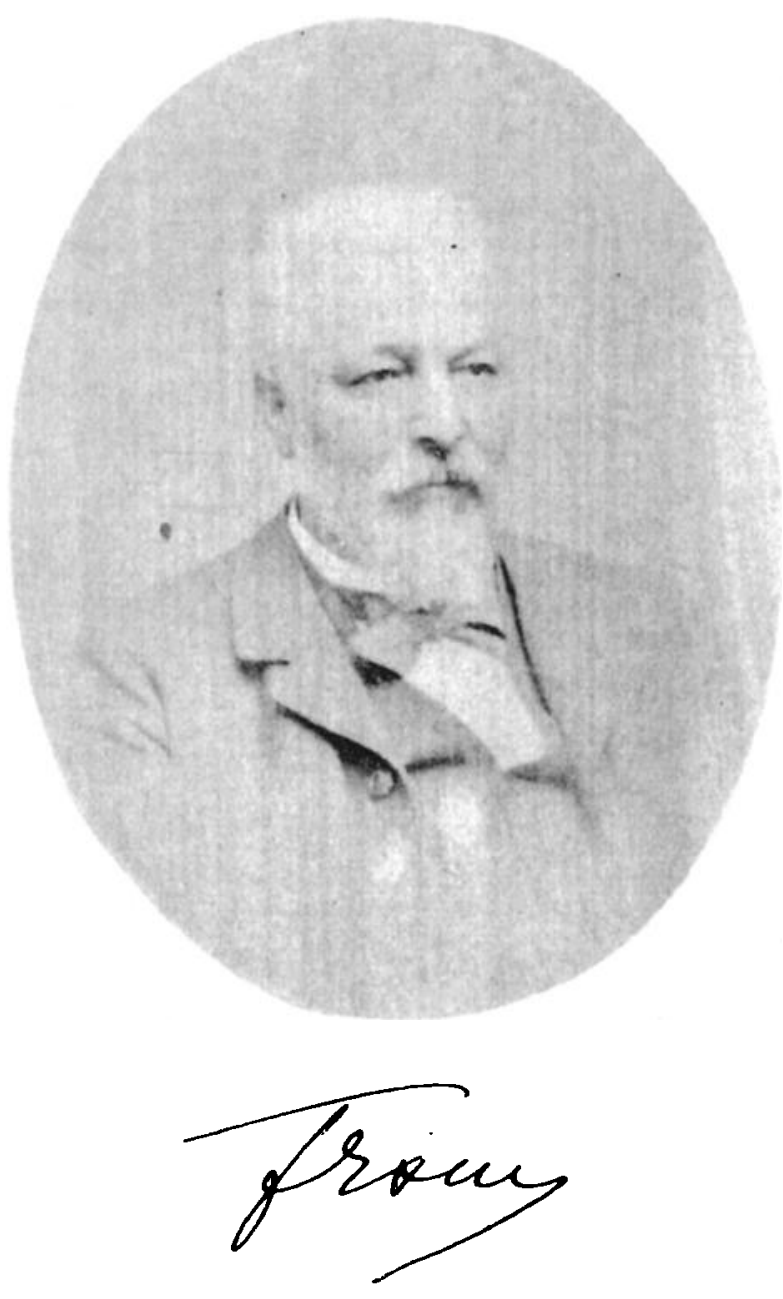


Dr. Fr. Bidlingmaier, of Lauffen, magnetic and meteorological observations will be continuously recorded for one year.

The British expedition, under the leadership of Commander Robert F. Scott, of the Royal Navy, has chosen as its base-station, the magnetic observatory at Christchurch, New Zealand, and departing from that place will occupy the Pacific side of the Antarctic regions as its field of investigation. A secondary base-station is to be established, if possible, in Victoria Land. The specialist in terrestrial magnetism of the expedition is Mr. Louis C. Bernachi, F. R. G. S.

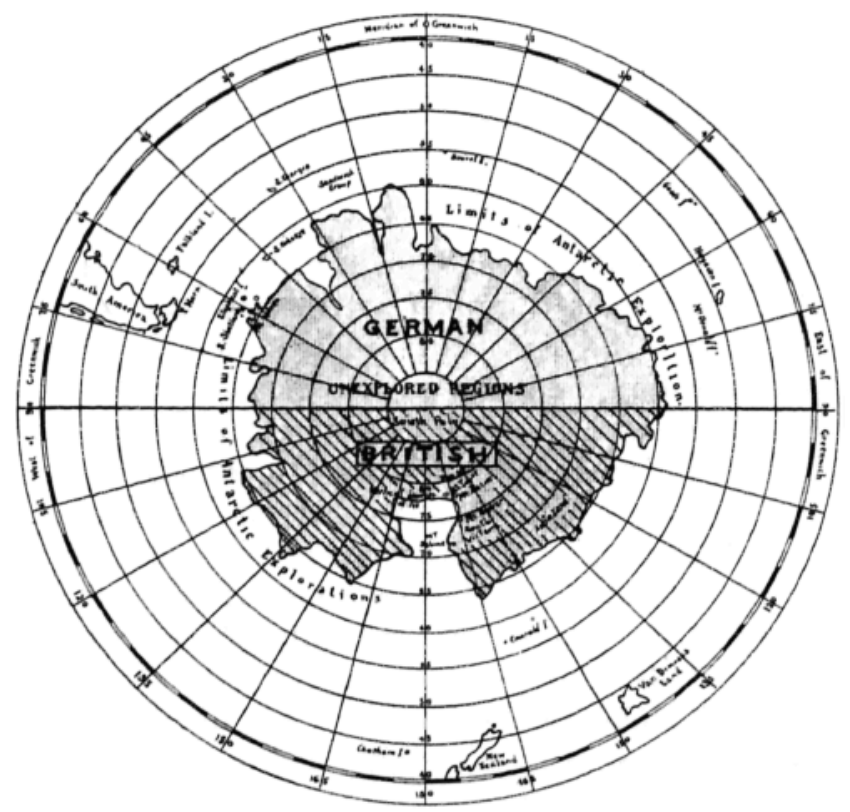

ANTARCTIC AREA, SHOWING ALLOTMENTS OF THE TWO EXPEDITIONS.

[For the above map we are indebted to Knowledge, June, I90I, issue.]

The program of observations of the two expeditions has been made a subject of international agreement, and has been communicated to all those States which possess magnetic and meteorological stations in order that there may be universal co-operation to secure the ends in view.

Termination Land will probably serve as an objective point for the German expedition, which will sail thence westward to find the 
west side of Victoria Land, to clear its possible connection with Kemp Land and Enderby Land, and then sail around the Antarctic lands on the Atlantic side.

The British expedition will probably sail eastward from Termination Land to explore the north side of Wilkes Land and then Victoria Land, the Great Ice Barrier, and the Pacific side of Antarctica.

The chief object of each expedition is to establish a scieutific station in the south polar region where geophysical investigations may be carried on continuously for a full year, and from which, as a base-station, excursions of a longer or shorter duration can be made for the accomplishment of projected observations.

The endeavor of the Germans will be to plant their station on the western side of Victoria Land, because the extensive land surface which may be looked for there will offer favorable opportunities for scientific investigation. Being near the magnetic pole, magnetic phenomena can be studied to good advantage, and the inland ice of Antarctica can best be ascended and studied where there is an extended land. Perhaps also a journey could be made from there toward the geographical pole. A large extent of land also affords much richer opportunities for studying animal and plant life as well as for geological and gravitational investigations.

To secure the same opportunities, the British expedition will endeavor to land on the east coast of Victoria Land, and will thus be in a position to afford ground for co-operation according to the highest standards of scientific knowledge for the investigation of whatever is characteristic of the Antarctic regions in the domain of terrestrial magnetism, geography, geology, glaciation, meteorology, and other branches of terrestrial physics.

Among the primary objects of both of the expeditions is research in the field of terrestrial magnetism with a view of completing and bringing up to date the magnetic work done by Ross in the Erebus and Terror, and by Moore and Clerk in the Pagoda, about sixty years ago. Since that time no accurate survey of these regions has been made, and, with the ever-changing variation of the needle by unknown amounts, navigation by the compass in the region south of the Cape of Good Hope has become uncertain.

The paramount necessity for securing reliable observations of the declination and inclination of the magnetic needle and of the intensity of the Earth's magnetic force, caused the projectors of the expeditions to design both expeditionary vessels with this special object in view, and it is certain that while at sea both expeditions 
will determine the magnetic elements each day by the standard compasses of their ships, and the inclination and intensity by the Creak and Fox dip-circles. Absolute measurements of the magnetic elements will be made whenever possible, either on the ice or on the land, and the relative instruments compared with them. For the land purpose a recording magnetograph of the Eschenhagen type will be set up to obtain self-registered records of the variations of the magnetic needle.

The Discovery is the name of the vessel in which the British expedition is to set forth. She is built on whaler lines, only with greatly increased strength to withstand the ice pressure, and has a length between perpendiculars of $I 7 I$ feet, a breadth of beam of $34 \mathrm{~T} / 2$ feet, a depth of hold of 17 feet, and a displacement of 1,500 tons.

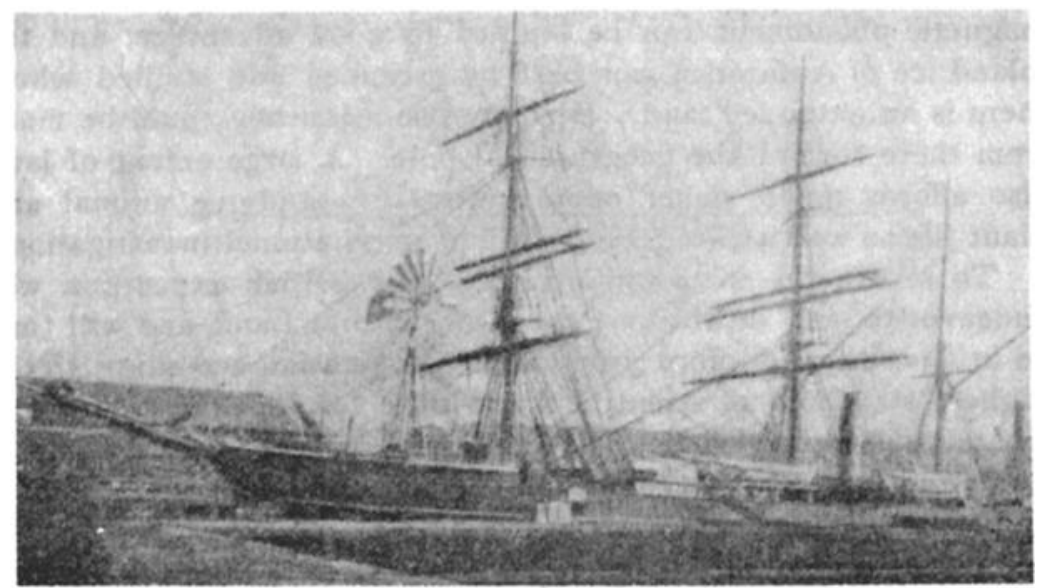

STIAMMR "DISCOVERY," SHOWING WINDMILL, ON DECK.

Her framing is constructed of Scottish oak, and where she will be subjected to the maximum pressure, heavy transverse bulkheads are supplied. There is a solid mass of wood nine feet in thickness in her stem, while her sides amidships are $2 \mathrm{r} / 2$ feet thick. Her outside planking is of hard wood sheathed with green-heart and iron bark. Owing to the peculiarity of her form, when the ice exerts heavy pressure, instead of crushing the vessel, it will gradually lift her up. She belongs to the auxiliary class of steam vessels, her engines developing only $45^{\circ}$ horse-power, and she will 
thus depend mainly for progress on her sails, with which she is rigged as a bark. She is driven by three propellers fitted with withdrawing shafts and lifting screws, by which means, whenever an exigency arises, the screw shaft can be withdrawn inboard out of the way of the ice. Her boilers are of the best return-tube Scotch type. Her coal capacity is 280 tons, but this is sufficient to carry her 8,000 knots at an average speed of $6 \mathrm{t} / 2$ to 7 knots per hour. She carries a steam dynamo and also a windmill dynamo, for generating the electric current to be utilized in lighting the ship.

The internal arrangements of the vessel are as comfortable as possible. There is the usual range of laboratories and workshops incidental to such expeditions, and roomy quarters for the officers and crew. One prominent feature of the interior equipment is a kind of atmospheric lock by which means the raw Antarctic air is

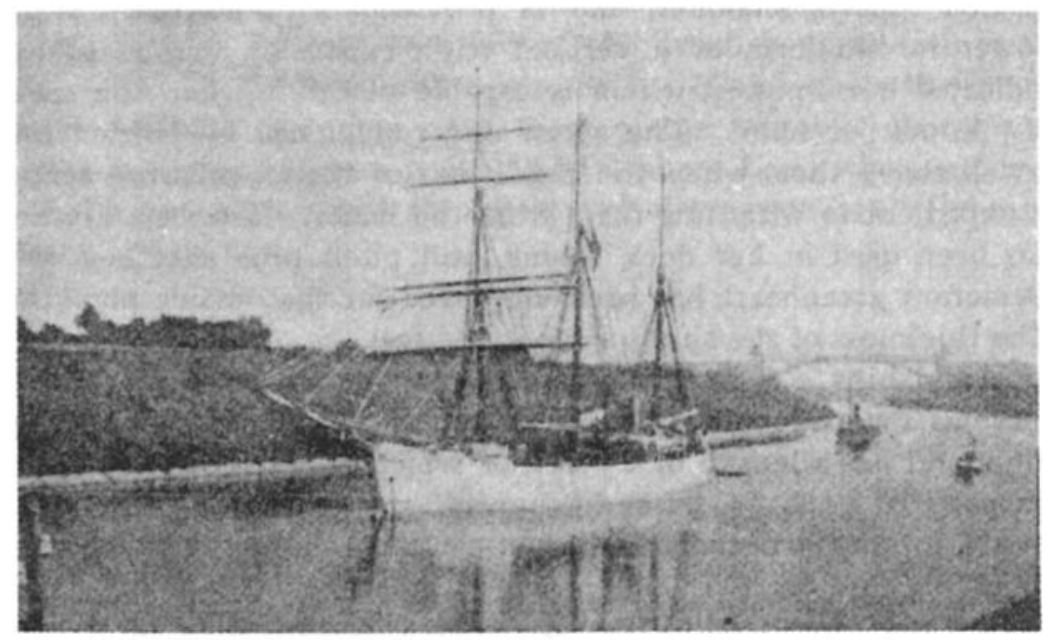

STHamer "gaUss," passing through the kaiser wizhelm canal.

prevented from entering the interior of the vessel when a person enters from the deck. It is a double-door arrangement, and when entering, the person first closes the outer door before he opens the one leading into the apartment. To preserve the warmth of the rooms the walls are lined with asbestos. The stoves are provided with talc doors, having funnel-like fittings over them, through which the air from the outside enters, and is carried over glowing coals to be heated prior to its delivery into the rooms.

To guard against the derangement of the magnetic instruments, 
upon whose effective use so much of the utility of the expedition depends, the overhead rigging has been made of hemp in all those parts which from their position might introduce magnetic disturbance, and all steel and iron have been excluded from the construction of the vessel within a radius of 30 feet of them.

The German vessel, which is significantly named the Gauss, is commanded by Hans Ruser, of Hamburg, a captain in the Hamburg-American line, who was appointed with the Emperor's approval. The Gauss is a stanch and seaworthy wooden ship, built to withstand great pressure, but not of the Fram's pattern, as the dangers from pressure of ice are thought to be less in the south polar regions than in the north. She has a length between perpendiculars of $15 \mathrm{I}$ feet, a breadth of beam of 36 feet, a depth of hold of 16 feet, and a displacement of 1,450 tons. She is rigged as a threemasted topsail schooner, and is provided with auxiliary steam power in the form of a vertical triple-expansion engine of 275 indicated horse-power, which is capable of driving her at a speed of 7 knots per hour. The screw and rudder can be hoisted into a well above them when the conditions of the ice-pressure render it expedient to withdraw them from the water. The best dry oak has been used in her deck beams, and pitch pine sheathed with Demerara greenheart has been employed for the outside planking. The thickness of the ship's sides is $21 / 2$ feet.

Amidships, a deck house of teak and fir has been provided to serve as a work-room for the scientific staff. This house is $61 / 2$ feet high, and has a length of 25 feet, of which 8 feet is devoted to the purposes of a chart-room and gangway.

On top of the deck house is the captain's bridge, well sheltered by a structure of teak, and provided at each end with oil tanks from which pipes lead to the ship's sides for providing oil to calm the sea in rough weather.

On the bridge is a revolving table for magnetic observations, within a radius of 27 feet of which bronze fittings have been used to the exclusion of iron and steel.

There is another room amidships having a length of about is feet, which is mainly used for the storage of instruments, for which purpose it has been designed with extraordinary care.

A photographic darkroom, a drying-room, and a bathroom are also placed amidships, while the kitchen is located between the boiler and engine-room batches.

Steam heating is furnished to all of the living and working 
rooms, bath and wash rooms, mess and chart rooms. The heaters are large enough to provide a temperature of $+10^{\circ}$ Centigrade with an outdoor temperature of $-30^{\circ}$ Centigrade. In addition to the steam-heating apparatus, iron stoves are provided for the messrooms, workrooms, and the passages between the staterooms.

Electric lighting is installed throughout the ship, power being furnished by a dynamo which can be connected with an accumulator battery.

The fuel supply consists of $45^{\circ}$ tons of cardiff coal, together with five tons of petroleum and naptha in iron tanks stored on deck.

Besides the two main expeditions related above, there will be one from Sweden, under the leadership of Dr. Otto Nordenskiöld, of Upsala University, and another from Scotland, under the leadership of Mr. Wm. S. Bruce. The ship of the Swedish expedition is the Antarctic; the projected route is to Staten Island where the instruments will be compared with those of the magnetic observatory noted below, and thence probably to Graham Land where observations, in accordance with the international program, are to be made for one year.

The Argentine Republic, through the efforts of Dr. Don Francisco Moreno, has established a magnetic observatory on Staten Island.

\section{RECENT NEWS REGARDING THE EXPEDITIONS.}

The Antarctic left Götenburg, Sweden, on October r6th. According to a Reuter message, Professor Nordenskjöld has made the following statement to a Press representative as to the plan and object of his expedition: "From Götenburg we shall proceed to England, and thence to Buenos Ayres and Terra del Fuego, whence we shall make our way to the Antarctic regions. We shall endeavor to push as far south as possible with the Antarctic; and, when winter comes on, we shall send a party on shore to winter. That party will probably consist of six persons, of whom I shall be one. We shall build a small hut for ourselves, and engage in meteorological, magnetic, hydrographic, and other scientific observations. As soon as we have landed, the Antarctic will return to Terra del Fuego, and a scientific observer, who will sail with her, will conduct the researches in that hitherto little-explored country. In this way we shall be able to work in two detachments, and make as much use of our time as possible. Professor Ohlin, of Lund, and M. K. A. Andersson, will accompany me as zoologists; Dr. Bodman will come as hydrographer and magnetician; M. Skottoburg as botanist, and Dr. E. Ekolof as 
medical officer. Captain Larsin, who has already made several voyages to South Polar regions, will be in charge of the Antarctic."

As the Journal is passing through the press, the following information regarding the English and German expeditions has been obtained: It was part of the instructions of the expedition that the Discovery should proceed southwards towards the point of maximum total magnetic force. The dispatches received by the Times, state that on November I2, rgor, in latitude $50^{\circ} \mathrm{S}$.; longitude $13 \mathrm{r}^{\circ} \mathrm{E}$., Captain Scott determined to turn southwards towards this focus, running more or less on the line of no variation. The result was a very gradual increase of total force, while there were other points of interest in the observations of the dip and variation. The Discovery continued to push southwards till November I6th, when the first ice was sighted. On November 16th, a sounding was taken in 2,300 fathoms, while the magnetic observations showed a dip of $86^{\circ}$. The farthest south point reached was $62^{\circ} 5^{\prime}$ in longitude $139^{\circ} 40^{\prime} \mathrm{E}$. The Discovery turned northeastwards on November $I 7$ th, and on the I8th a sounding was made in $I, 75^{\circ}$ fathoms. Captain Scott then made as rapidly as possible for his destination in New Zealand, and Lyttelton was reached on November 28th. The necessary shore magnetic observations were made at the Christchurch Magnetic Observatory. The Discovery has since then turned her face southwards to enter upon the real work of the expedition.

The steamer Miowera which arrived at Victoria, B. C., on February 2 rst, from Australia, brought the first reports from the German expedition. The steamer Tanglin, which took stores to Kerguelen Island for the German South Polar ship Gauss, returned to Sydney before the liner sailed. The Tanglin had landed 88 dogs, coal, stores and building material for the Gauss, and debarked two of the members of the expedition-Herr Enzensperger and Dr. Luyken, together witb three Russian dog tenders.

After a stormy trip, the Tanglin arrived off Kerguelen Island, where a landing was made, the German flag run up, and a bottle left, with instructions for the commander of the Gauss expedition as to where the stores were to be found. The two gentlemen of the expedition went ashore and located a place for the erection of an observatory. The house erected by the English expedition was still standing, but much out of repair, and it was decided to remove it and erect a new one. 